DOI: $10.34010 /$ agregasi.v8i1.3061

Available online at: https://ojs.unikom.ac.id/index.php/agregasi

\title{
KONFLIK PEMBANGUNAN PETERNAKAN AYAM DI KECAMATAN GUNUNG KENCANA
}

\author{
Dede Surya Lesmana ${ }^{1}$, Aulia Prima Rahman Yunas ${ }^{2}$, Naufal Syafiq Permana ${ }^{3}$ \\ 1,2,3 Program Studi Ilmu Pemerintahan, Fakultas Ilmu Sosial dan Ilmu Politik, Universitas Sultan \\ Ageng Tirtayasa, Jl. Raya Jakarta Km 4 Pakupatan Kota Serang \\ Provinsi Banten, Indonesia \\ Email: dedesuryalesmanaskr@gmail.com, auliaprimarahman@gmail.com, \\ syafiqnaufalp@gmail.com
}

\begin{abstract}
Abstrak
Penelitian ini bertujuan untuk menggambarkan konflik yang terjadi di Desa Ciakar Kecamatan Gunung Kencana akibat adanya pendirian peternakan ayam di tengah pemukiman masyarakat. Konflik ini berawal dari keresahan masyarakat sekitar yang menganggap bahwa jika pendirian peternakan tetap dilanjutkan dapat mengganggu kenyamanan lingkungan, karena akan menimbulkan bau busuk dari kotoran ayam. Teori yang digunakan dalam penelitian ini adalah teori gerakan sosial menurut Jean Cohen yang didukung dengan teori politik lingkungan dan teori konflik. Metode yang digunakan dalam penelitian ini adalah metode kualitatif deskriptif. Pengumpulan data dalam penelitian ini melalui wawancara, observasi, dan studi dokumen. Hasil penelitian menunjukkan bahwa konflik pendirian peternakan ayam berujung pada munculnya gerakan sosial penolakan yang dilakukan oleh masayarakat kepada pemerintah melalui jalaur audiensi dengan mengumpulkan KTP masayarakat yang menolak, kemudian didukung oleh surat penolakan yang dilayangkan oleh Himpunan Mahasiswa Gunung Kencana. Gerakan penolakan yang dilakukan oleh masayarakat ini disambut baik oleh pemerintah karena pendirian peternakan ayam tersebut tidak memiliki izin, akan mengganggu kenyamanan lingkungan, serta melanggar PERDA Kaupaten Lebak No.2 Tahun 2014 tentang rencana tata ruang wilayah (RTRW) dan peraturan daerah No.9 Tahun 2010 tentang retribusi perijinan tertentu.
\end{abstract}

Kata kunci: Gerakan Sosial, Politik Lingkungan, Peternakan Ayam

\section{CONFLICT ON CHICKEN FARM DEVELOPMENT IN GUNUNG KENCANA DISTRICT}

\begin{abstract}
This study discusses the conflict that occurred in Ciakar Village, Gunung Kencana District due to the existence of a chicken farm in the middle of a community settlement. This conflict originated from the unrest of the surrounding community who considered the development of livestock that could be approved for environmental comfort, because it would cause a foul odor from chicken manure. The theory used in this study is the theory of social movements according to Jean Cohen which is supported by environmental political theory and conflict theory. The method used in this research is descriptive qualitative method. Collecting data in this study through interviews, observation, and study documents. The results of research that prove the conflict carried out by chickens that led to the transition of social movements conducted by the community to the government through the audience channel by collecting community ID cards that refused, then supported by a letter posted by the Gunung Kencana Student Association. The movement carried out by the community was attractive both by the government because the office negotiations had permits, office comfort offices, and Perda Regional Regulation No. 2 of 2014 concerning regional spatial plans (RTRW) and regional regulations No.9 of 2010 concerning licensing fees. certain.
\end{abstract}

Keyword: Social Movement, Environmental Politics, Chicken farm 
DOI: $10.34010 /$ agregasi.v8i1.3061

Available online at: https://ojs.unikom.ac.id/index.php/agregasi

\section{PENDAHULUAN}

Kurangnya kesadaran masyarakat terhadap upaya pelestarian lingkungan dapat memunculkan terjadinya pencemaran lingkungan. Pencemaran lingkungan dalam hal ini terjadi akibat pembuangan limbah secara sembarangan, baik itu ke tanah ataupun ke media lainnya. Pembuangan limbah secara sembarangan ini dapat mengganggu banyak orang apabila dibiarkan begitu saja atau tanpa tindak lanjut. Tetapi mengganggu disini sifatnya relatif, tergantung pada jenis limbah dari pabrik itu sendiri, begitupun efek yang ditimbulkan dari limbah yang dibuang sembarang tersebut juga tergantung pada jenis limbah yang dibuangnya. Selain itu sifat mengganggunya pun berbeda-beda, karena suatu limbah dapat dikatakan mengganggu apabila pembuangannya tidak sesuai dengan yang seharusnya. Suatu limbah dapat dikatakan mencemari lingkungan juga apabila tidak memperhatikan dampak lingkungan ataupun tidak diseimbangkan dengan kebijakan analisis mengenai dampak lingkungan (AMDAL) yang harus dipenuhi sebelum izin operasional pabrik.

Berbicara mengenai pencemaran lingkungan fokus kajian dalam penelitian ini akan mencermati potensi pencemaran lingkungan yang terjadi akibat didirikannya peternakan ayam yang berlokasi di Desa Ciakar kecamatan Gunung Kencana Kabupaten Lebak yang ditolak oleh masyarakat setempat dan organisasi masyarakat melalui sebuah gerakan yang masif. Pencemaran lingkungan dalam pendirian peternakan ayam ini pada dasarnya tidak berdampak atau tidak memberikan kerugian pada lingkungan abiotik seperti tanah, air ataupun udara. Akan tetapi pencemaran disini lebih pada masyarakat yang akan merasa terganggu akibat bau busuk yang akan ditimbulkan oleh kotoran ayam ternak, terlebih bangunan perternakan yang didirikan dilokasi tersebut berada di tengah pemukiman warga serta direncanakan memiliki bangunan yang luas atau perternakan berskala besar, yang tentunya akan diisi ayam ternak dalam jumlah banyak pula. Alhasil berangkat dari hal tersebut sangat wajar apabila masyarakat melakukan protes ataupun unjuk rasa kepada pemerintah dan pemilik pabrik apabila membayangkan kondisi tersebut.

Jika dilihat dengan pendekatan sosial-ekologis pencemaran lingkungan akibat rencana didirikannya peternakan ayam ini menuai kritik dari masyarakat atas dasar pertimbangan lingkungan yang spesifiknya adalah udara yang tercemar dengan bau kotoran ayam. Walaupun seperti yang telah disinggung diawal bahawa pencemaran ini tidak berdampak pada lingkungan abiotik namun akan tetap mengganggu.

Imbas dari rencana pendirian peternakan ayam ini kemudian menuai konflik dan penolakan dari masyarakat setempat sebagai upaya untuk meminimalisir terjadinya ketidaknyamanan setelah pabrik selesai dibangun dan diisi sejumlah ayam. Disamping itu pendirian peternakan 
DOI: $10.34010 /$ agregasi.v8i1.3061

Available online at: https://ojs.unikom.ac.id/index.php/agregasi

ayam di Desa Ciakar juga dianggap melanggar peraturan daerah Kabupaten Lebak Nomor 9 tahun 2010 tentang retribusi perizinan tertentu dan Peraturan daerah Kabupaten Lebak Nomor 2 tahun 2014 tentang RTRW. Karena wilayah ini merupakan pemukiman warga dan secara tata ruang Gunung Kencana juga bukan untuk peternakan. Sehingga dalam rencana pendirian peternakan ini harus mempertimbangkan sisi sosial dan etika yang berlaku.

Kemudian berbicara mengenai konflik, Veeger (Veeger, 1985) menjelaskan bahwa konflik ada beberapa jenis, yaitu konflik kecil (individu dengan individu) dan konflik besar (kelompok dengan kelompok). Dalam hal ini konflik yang terjadi merupakan konflik besar karena menimbulkan keresahan di masyarakat yang berujung pada unjuk rasa kepada pemerintah, audiensi, hingga meminta bantuan salah satu ormas yang ada di Kecamatan Gunung Kencana. Hal ini sesuai dengan pernyataan Turner (Mas'udi, 2015) bahwa kericuhan dan unjuk rasa bisa terjadi karena adanya kekuasaan, kepentingan, dan kelompok penyebab konflik. Yang berakibat pada semakin besarnya derajat emosional suatu konflik yang terjadi di masyarakat. Pernyataan Turner tersebut sesuai dengan konflik yang terjadi akibat pendirian peternakan ayam di kecamatan gunung kencana ini. Yang mana konflik dimulai dengan adanya kekuasaan yang dimiliki oleh kepala desa sebagai pemimpin untuk memberikan izin untuk pendirian peternakan ayam kepada pemilik pabrik yang memiliki modal besar dengan cara mengumpulkan KTP masyarakat sebagai bukti bahwa banyaknya masyarakat yang setuju terhadap rencana pendirian peternakan ayam tersebut, walaupun faktanya kepala desa bisa mendapatkan fotokopi KTP masyarakat tanpa harus memintanya karena dibeberapa kesempatan dalam penyelenggarakan program desa sesekali kepala desa akan mengumpulkan KTP masyarakat untuk kepentingan administratif. Selanjutnya jika dilihat lebih jauh kasus ini juga berhubungan dengan kepentingan, dimana kepala desa dalam hal ini terlihat memiliki kepentingan tertentu sehingga dengan mudah memberikan izin kepada pengusaha untuk mendirikan peternakan tanpa mempertimbangkan efek lingkungan yang terjadi dan aspek sosial kemasyarakatan. Kemudian dalam konflik ini terlihat adanya kelompok yang berperan yaitu HIMAGUNA (Himpunan Mahasiswa Gunung Kencana).

Selanjutnya melihat konflik lingkungan yang terjadi di Desa Ciakar ini menunjukan adanya proses atau tahapan yang beruntun pada konflik tersebut, yaitu: sadarnya masyarakat bahwa didirikannya peternakan ayam akan mengganggu kenyamanan; terjadinya interaksi antara satu masyarakat dengan masyarakat lain yang menyadari hal yang sama; munculnya ketidak sepakatan masyarakat dalam pendirian peternakan; adanya pengkajian kasus 
DOI: $10.34010 /$ agregasi.v8i1.3061

Available online at: https://ojs.unikom.ac.id/index.php/agregasi

oleh masyarakat beserta ormas yang ada (HIMAGUNA); dan terjadinya audiensi yang diikuti unjuk rasa.

Lebih lanjut konflik yang terjadi akibat didirikannya peternakan ayam ini dimulai dengan adanya pernyataan pemahaman dan penyataan sikap warga yang diaplikasikan dalam bentuk protes yang berujung audiensi dan unjuk rasa. Menyikapi hal tersebut tindakan unjuk rasa yang dilakukan masyarakat ini dapat dikategorikan pada bentuk kolektivis (asosiasi individu-individu) dan individualis (individu terpisah dari asosiasi) (Sargent, 1986).

Dalam proses penyelesaian konflik akibat ketidaknyamanan lingkungan ini, pada awalnya digagas oleh beberapa tokoh masyarakat atau orang berpengaruh lainnya yang melapor kepada pihak pemerintah Kecamatan Gunung Kencana untuk kemudian meninjau kembali perizinan pendirian peternakan yang telah dibangun tersebut dengan memperhatikan beberapa aspek, seperti aspek kenyamanan lingkungan, penegakan aturan, dan aspek sosial yang akan terjadi akibat konflik. Akan tetapi pada prakteknya pemerintah Kecamatan Gunung Kencana tidak langsung menindak lanjuti begitu saja pengaduan masyarakat karena dianggap telah mendapatkan izin yang resmi dari kepala desa setempat, sehingga hal tersebut memunculkan kekesalan dari masyarakat yang akhirnya berujung pada pengaduan terhadap salah satu ormas di Kecamatan Gunung Kencana yaitu HIMAGUNA. Selanjutnya
HIMAGUNA melayangkan surat resmi yang berisi protes terhadap pemerintah kecamatan Gunung Kecana atas perizinan pendirian peternakan ayam di Desa Ciakar yang dianggap mengganggu kenyamanan warga, serta protes akibat tidak digubrisnya pengaduan masyarakat yang telah dilayangkan sebelumnya. Dalam hal ini masyarakat sipil informal yang saling mempengaruhi satu sama lain serta adanya keterlibatan HIMAGUNA dalam penyelesaian konflik ini sesuai dengan pandangan strukturalisme dan post-strukturalisme Giddens (Giddens, 1984) yang menyatakan bahwa seorang aktor menekankan sifat aktif dan refleksif dari perilaku manusia. Sedangkan aksi penolakan dan protes yang dipengaruhi oleh aktor merupakan bagian dari gerakan sosial dan perjuanganperjungan lingkungan (safety ecologies).

Berangkat dari hal diatas pada penelitian kali ini, peneliti akan mencoba melihat bagaimana konflik yang terjadi akibat pendirian peternakan ayam di Kecamatan Gunung Kencana tersebut dengan melihat aktor-aktor yang terlibat dalam konflik maupun yang menyebabkan terjadinya konflik serta bagaimana konflik ini bisa terselesaikan melalui perantara HIMAGUNA sebagai salah satu ormas yang aktif dalam gerakan sosial di kecamatan Gunung Kencana.

Menurut Jean Cohen (Cahyono, 2018) Gerakan sosial baru di masa kapitalisme leberal saat ini tidak hanya timbul dari kalangan buruh yang terlibat dalam produksi saja seperti pada 
DOI: $10.34010 /$ agregasi.v8i1.3061

Available online at: https://ojs.unikom.ac.id/index.php/agregasi

gerakan sosial lama, dimana pada gerakan sosial lama, gerakan sosial didominasi oleh gerakan kelas proletar seperti buruh yang menuntut keadilan kepada kelas borjuis seperti kaum kapitalis. Di era sekarang ini gerakan sosial muncul dari berbagai sudut dan dari berbagai kalangan, begitupun dengan tuntutan yang diadvokasikannya pun turut beragam pula. Gerakan sosial baru di era sekarang ini muncul dari kaum urban, kaum marginal, mahasiswa, aum menengah, dan juga dari masyarakat biasa. Gerakan sosial baru meletakan konsepsi ideologisnya bahwa kini masyarakat sipil sudah meluruh dan ruang sosialnya telah mengalami penyempitan akibat menguatnya kontrol negara. Alhasil secara radikal gerakan sosial baru membantah pandangan marxis yang menjelaskan konflik dan kontradiksi dalam istilah kelas dan konflik kelas. Berangkat dari hal itu maka gerakan sosial baru diartikan sebagai gerakan tanpa kelas dan menjadi sumber perhatian anti materialistik. Oleh karena itu gerakan sosial baru lebih mengedepankan gerakan-gerakan sosial akar rumput dari pada gerakan sosial yang melibatkan organisasi-organisasi serikat industri dan kepartaian. Gerakan sosial baru lebih mengedepankan tujuan, pluralitas, cita-cita, kehendak dan orientasi multikultural yang berbasis sosial (Oktaviana, 2015).

Cohen (Situmorang, 2007) juga menyatakan bahwa terdapat empat batasan dalam gerakan sosial baru, yaitu perjuangan aktor-aktor dalam gerakan sosial baru bukan untuk mengembalikan komunitas-komunitas utopia masa lalu; mengedepanakan perjuangan pluralitas dan otonomi; adanya upaya sadar dari aktor yang terlibat untuk merelatifkan nilai-nilai melalui penalaran serta belajar dari masa lalu; dan aktor yang terlibat tetap memperhatikan keadaan ekonomi pasar dan situasi formal negara. Dengan demikian maka inti dari gerakan sosial baru adalah untuk menciptakan kebebasan publik yang otonom dan demokratis guna membangun kembali relasi negara, perekonimian negara, serta masyarakat secara harmonis.

Kemunculan gerakan sosial baru ini dapat kita lihat dari semakin marakanya gerakan perlawanan dari berbagai kalangan, mulai dari mahasiswa, kalangan profesional, aktivis perempuan, aktivis keagamaan, aktivis minoritas, aktivis lingkungan, aktivis anti korupsi dan lain sebagainya. Selain itu dalam gerakan sosial baru ini juga tidak terpaku pada isu perbedaan kelas dan isu buruh semata, melainkan lebih luas lagi seperti isu kekerasan seksual, marginalisasi, kesenjangan sosial, isu pendidikan, isu korupsi dan isu lingkungan yang kini sedangan banyak diperbincangkan (Singh, 2010).

Adapaun untuk melihat parameter gerakan sosial baru, Cohen berpendapat bahawa ada tiga parameter, yaitu struktur persamaan politik, strukur mobilisasi massa, dan juga framing atau pembingkaian (Arfiyani, 2014).

Berbicara mengenai gerakan sosial baru, maka kita tidak bisa terlepas dari gerakan sosial yang memeperjuangkan kelestarian 
DOI: $10.34010 /$ agregasi.v8i1.3061

Available online at: https://ojs.unikom.ac.id/index.php/agregasi

lingkungan, atau dewasa ini banyak yang menyebutnya sebagai politik ligkungan. Dalam gerakan sosial yang berhubungan dengan politik lingkungan, tentunya kajian utamanya adalah tentang lingkungan dan juga keleestariannya. Menurut Yeni Sri Lestari (Lestari, 2016) dalam jurnalanya disebutkan bahwa isu mengenai gerakan lingkungan ini sangat erat kaitannya dengan ekonomi politik, ia mengemukakan bahwa fungsi lingkungan seringkali dikesampingkan oleh banyak kalangan ekonom konvensional demi memenuhi kepentingan ekonominya. Hal ini bisa dilihat dari kepentingan lingkungan itu sendiri untuk kegiatan ekonomi. Dimana lingkungan merupakan sumber dari segala kebutuhan materi dan energi, namun seringkali diajadikan tempat utama pembuangan sisa atau limbah industri hasil perekonomian sutau perusahan atau negara secara semabarangan.

Politik lingkungan serta gerakan pelestarian lingkukungan ini menjadi penting, karena pada intinya menurut WALHI merupakan gerakan sosial dan politik yang didesain untuk melestarikan lingkungan, melakukan restorasi dan peningkatan kualitas hidup melalui pendidikan publik, advokasi perubahan gaya hidup, perbaikan perencanaan komunitas, perubahan ekonomi uang dan perombakan kebijakan negara. Environmentalisme diartikan sebagai gerakan sosial karena konsen dari gerakannya banyak berfokus pada permasalahan sosial yang berhububgan dengan manusia dan mahluk hidup lainnya. gerakan lingkungan juga diartikan sebagai gerakan politik/politik lingkungan karena tujuan dari gerakannya merupakan bagian dari upaya untuk menyelesaikan permasalahan lingkungan dengan melibatkan pemerintah atau negara serta menuntut kebijakan penyelesaiananya kepada pemerintah atau negara (WALHI, 2008).

Membahas mengenai gerakan sosial yang terjadi akibat adanya isu politik lingkungan yang berkembang di masyarakat, maka sejatinya kedua hal tersebut berawal dari adanya konflik di masyarakat yang merasa tidak mendapatkan hak mereka ataupun merasa tidak mendapatkan keadilan maupun merasa terganggu atas perkara tertentu. Maka dari itu konflik menjadi penting untuk dikajii karena merupakan awal mula terjadinya suatu gerakan yang memunculkan terjadinya gerakan sosial. Wes Sharrock (Saifuddin, 2009) menerangkan bahwa konflik dibangun dari asumsi yang berkembang di masyarakat yang menganggap bahwa setiap individu dapat memberikan kehidupan yang baik kepada individu lainnya, akan tetapi biasanya hal ini hanya bisa terjadi apabila ada diantara satu dan yang lain yang ditekan. Oleh karena itu, perbedaan kepentingan di masyarakat sama halnya dengan kesepakatan atas nilai dan aturan, dan mayoritas masyarakat diorganisir sedemikian rupa sehingga masyarakat tidak hanya memberikan manfaat lebih besar bagi masyarakat lainnya, akan tetapi juga memberikan 
DOI: $10.34010 /$ agregasi.v8i1.3061

Available online at: https://ojs.unikom.ac.id/index.php/agregasi

ketidaknyamanan bagi masyarakat yang lain yang tidak memperoleh kemudahan. Menanggapi pembahasan mengenai konflik diatas, Turner (Mas'udi, 2015) menjelaskan bahwa kemunculan beberapa kelompok dalam sitem sosial bisa menjadi penyebab munculnya target-target tertentu dalam eksistensi masing-masing. Beradasar dari hal tersebutlah akan muncul kesadaran dari masing-masing individu ataupun kelompok mengenai tujuantujuan tertentu yang ingin diwujudkan yang pada akhirnya mampu memunculkan konflik di masyarakat. Sejatinya, kebenaran atas kesepahaman dari unsur-unsur individu dalam kehidupan sosial masyarakat merupakan titik keseimbangan equilibrium yang ingin dicapai, akan tetapi pada hakikatnya, perjalanan sosial tersebut akan berdialektika dalam dimensidimensi yang senantiasa mengiringinya.

Berangkat dari ketiga teori diatas, maka dalam penelitian ini peneliti akan mencoba untuk menganalisis konflik pendirian peternakan ayam yang terjadi di Kecamatan Gunung Kencana yang ditinjau dengan menggunakan teori gerakan sosial, teori politik lingkungan dan juga teori konflik. Teori gerakan sosial digunakan untuk melihat sejauh mana gerakan kelompok masyarakat atau organisasi yang ada di Kecamatan Gunung Kencana mampu mempengaruhi kebijakan pemerintah Kecamatan Gunung Kencana untuk menghentikan pendirian peternakan ayam yang sedang berlangsung, serta untuk melihat sejauh mana gerakan sosial yang dibangun mampu mengakomodir semua kepentingan masyarakat yang terdampak. Teori Politik Lingkungan digunakan untuk menganalisis sejauh mana kebijakan pemerintah atau negara mampu memberikan dampak yang besar bagi kelestarian lingkungan dan hubungannya dengan masyarakat sekitar. Teori Konflik digunakan untuk menganalisis konflik yang terjadi antara masyarakat sebagai objek yang merasa tidak nyaman atas pendirian peternakan ayam, pihak perusahaan selaku subjek yang memiliki kepentingan ekonomi di tengah-tengah lingkungan masyarakat, pemerintah selaku pemangku kebijakan dan pemegang izin atas pendirian peternakan, serta HIMAGUNA selaku ormas yang turut berperan sebagai intermediari dalam mengadvokasikan kepentingan masyarakat kepada pemerintah.

\section{METODE}

Data ini didapat berangkat dari hasil peneilitian menggunakan metode kualitatif deskriptif. Pendekatan ini digunakan untuk mengungkapkan fenomena sosial politik dengan jelas dan cermat. Penelitian ini berupaya untuk menggambarkan mengenai konflik pembangunan peternakan ayam khususnya di Kecamatan Gunung Kencana, Kabupaten Lebak. Sumber data yang diambil dalam penelitian ini adalah wawancara, observasi, dan kajian dokumentasi untuk mendapatkan pemahaman yang lebih akurat terhadap data yang telah dikumpulkan. 
DOI: $10.34010 /$ agregasi.v8i1.3061

\section{PEMBAHASAN}

\section{A. Pembangunan Peternakan Ayam}

Pembangunan peternakan ayam di Gunung Kencana dimulai pada bulan Desember 2019 Yang berlokasi di Kampung Cikole lebih tepatnya di Desa Ciakar. Peternakan Ayam yang dibangun ini merupakan usaha milik seorang pengusaha yang bernama Rizaldi, beliau merupakan warga asli Gunung Kencana. Rizaldi membangun Peternakan Ayam ditempat ini dengan membeli tanah dari Busro seluas $10.852 \mathrm{~m}^{2}$ dengan harga lebih dari Rp 250.000.000,- Rencananya peternakan ayam yang dibangun akan dimiliki luas yang cukup besar serta didukung oleh fasilitas-fasilitas lainnya yang dapat digunakan oleh pegawai seperti rumah tempat menginap dan beberapa kamar mandi. Pembangunan peternakan ayam ini diborong oleh seorang pemborong proyek bangunan yang bernama Afrizal. Proyek pembangunan peternakan ini rencananya akan rampung pada bulan April mendatang.

$$
\text { Dibalik pembangunan }
$$

peternakan ayam milik Rizaldi yang diborong oleh Afrizal ternyata belum mengantongi izin dari pemerintah setempat melainkan mereka hanya membangun peternakan ayam atas dasar persetujuan dari beberapa masyarakat yang dimintai KTP nya oleh pemilik peternakan melalui sebuah perkumpulan yang diadakan oleh pemilik peternakan, dan menurut pemilik peternakan ayam bahwa semua masyarakat yang hadir pada perkumpulan tersebut menyetujui pendirian peternakan ayam yang akan dibangun di kampung mereka. Selain itu Rizaldi juga selaku pengusaha pemilik peternakan ini diketahui bahwa dalam proses pendirian peternakan ini dibantu oleh beberapa TNI kenalannya sehingga memiliki keberanian untuk mendirikan peternakan ayam dilokasi yang tidak tepat. Akan tetapi dalam perkumpulan yang dilakukan Rizaldi kepada masyarakat, Rizaldi tidak mengundang pemerintah setempat seperti ketua RT, ketua RW, dan kepala desa untuk bermusyawarah. Alhasil pembangunan peternakan ayam pun didirikan begitu saja tanpa izin terlebih dahulu kepada pemerintah setempat. Padahal secara prosedur untuk mendirikan suatu bangunan, terlebih yang memiliki usaha didalamnya tentu harus melalui sistem birokrasi yang berlaku seperti meminta izin kepada Pemerintah Desa ataupun Kecamatan.

\section{B. Aksi Protes Dari Masyarakat}

Setelah pembangunan peternakan ini berjalan selama hampir satu bulan dan telah berdiri beberapa bangunan pendukungnya pula, barulah muncul aksi protes dari masyarakat yang pada awalnya hanya merupakan obrolan-obrolan kecil antar masyarakat dari satu mulut ke mulut lainnya, akan tetapi obrolan obrolan itu semakin meluas karena pendirian peternakan ayam bersekala besar yang akan dibangun di kampung Cikole ini tentu akan memiliki dampak terhadap 
DOI: $10.34010 /$ agregasi.v8i1.3061

Available online at: https://ojs.unikom.ac.id/index.php/agregasi

lingkungan sekitar, baik itu dampak positif maupun dampak negatif. Ketika berbicara dampak negatif dari pembangunan peternakan ayam ini tentu sedikit meresahkan masyarakat, mengingat setelah bangunan selesai maka akan diisi oleh ribuan ayam yang tentunya akan menghasilkan kotoran. Dari kotoran tersebut tentu akan berdampak pada udara disekitar kampung, yang mana udara yang tercium akan berbau busuk karena merupakan kotoran ayam yang akan menumpuk dalam jumlah banyak, terlebih bangunan peternakan ayam tersebut berada di dekat pemukiman warga, sehingga apabila bangunan telah selesai dan diisi oleh ribuan ayam maka artinya setiap hari masyarakat akan mencium bau kotoran ayam di lingkungan tempat tinggal mereka.

Berangkat dari keresahan diatas serta pertimbangan aspek lingkungan lainnya maka masyarakat Desa Ciakar kemudian melakukan musyawarah di balai Desa Ciakar untuk membahas kelanjutan peternakan yang dibangun di Kampung Cikole tersebut. Setelah melalui perdebatan panjang dengan meminta pendapat dari masyarakat yang hadir pada saat musyawarah, maka hasil akhirnya 240 orang masyarakat menyatakan merasa terganggu dan menolak pendirian peternakan ayam di Kampung Cikole tersebut. Adapun masyarakat yang menyatakan sikap menolak tersebut diminta untuk mengumpulkan KTP nya sebagai bukti penolakan serta menandatangani berkas penolakan yang di kolektif oleh salah seorang warga bernama Jajuli. Kemudian setelah melalui persetujuan dari masyarakat yang hadir serta setelah mendapatkan kelengkapan berkas, maka berkas penolakan tersebut diberikan kepada Pemerintah Kecamatan Gungung Kencana, yaitu langusng kepada Camat Kecamatan Gungung Kencana yang bernama Rahmat. Berawal dari nota kesepakan masyarakat Desa Ciakar yang menyatakan keberatannya terhadap pendirian peternakan ayam dikampung Cikole tersebut, serta dilampiri dengan bukti foto copy KTP dan tanda tangan masyarakat maka setelah dua hari surat masuk pihak pemerintah Kecamatan Gunung Kencana kemudian melakukan pengkajian kasus dengan mempertimbangkan berbagai hal, seperti: Pernyataan keberatan dari masyarakat; melihat prosedur perijinan pendirian peternakan; hasil pengecekan dilapangan; serta melihat PERDA Kabupaten Lebak No.2 Tahun 2014 tentang rencana tata ruang wilayah (RTRW) dan peraturan daerah No.9 Tahun 2010 tentang retribusi perijinan tertentu.

Berangkat dari beberapa pertimbangan diatas maka pada akhirnya tepat pada tanggal 30 Januari 2020 kegiatan pembangunan peternakan ayam tersebut dihentikan secara paksa oleh MUSPIKA kecamatan Gunung Kencana melalui surat edaran yang di tanda tangani oleh camat untuk pemilik peternakan yang bernama Rizaldi serta melalui dialog yang dilakukan oleh camat Kecamatan Gunung Kencana dengan pelaksana proyek yang bernama Afrizal. 
DOI: $10.34010 /$ agregasi.v8i1.3061

Available online at: https://ojs.unikom.ac.id/index.php/agregasi

Penghentian pembangunan pendirian peternakan ayam secara paksa ini dilakukan atas dasar keberatan dari masyarakat setempat yang meyakini bahwa ketika pembangunan peternakan ayam ini tetap dilanjutkan maka akan berdampak pada pencamaran udara yang berupa teciumnya bau busuk yang menyengat disekitar pemukiman warga yang berasal dari kotoran ayam, terlebih peternakan ayam yang dibangun akan berskala besar sehingga tentunya akan diisi oleh ayam yang berjumlah banyak dan memliki kotoran yang pastinya banyak pula. Walaupun pada dasarnya pembangunan peternakan ayam tersebut tidak akan berdampak pada pencemaran lingkungan seperti tanah dan pohon-pohon disekitar, akan tetapi walau demikian tetap saja akan mengganggu bagi masyarakat karena menimbulakan bau busuk.

Pertimbangan kedua, pendirian peternakan ayam ini dihentikan secara paksa karena tidak memiliki izin operasional yang jelas dari pemerintah setempat, sehingga dianggap tidak tertib administrasi dan melanggar aturan serta sistem birokrasi yang berlaku, karena berdasarkan penuturan Camat Kecamatan Gungung Kencana bahwa setiap masyarakat yang ingin mendirikan bangunan terutama yang akan digunakan untuk kegiatan wirausaha maka seharusnya melakukan perizinan terlebih dahulu kepada pemerintah setempat, terlebih pembangunan ini nantinya akan menjadi suatu usaha atau bisnis, sehingga harus mengantongi izin terlebih dahulu dari
Dinas Penanaman Modal Terpadu Satu Pintu (DPMPTSP) Kabupaten Lebak. Perizinan tersebut diperlukan agar sebelum dimulainya pendiriannya suatu bangunan, pemerintah bisa melakukan pengecekan terlebih dahulu mengenai tempat maupun jenis bangunan yang akan dibangun, agar tidak ada pihak yang dirugikan ataupun merasa terganggu atas didirikannya bangunan. Selain itu proses perizinan ini juga merupakan bagian dari upaya tertib administrasi bagi semua masyarakat.

Pertimbangan ketiga adalah setelah pihak Kecamatan Gunung Kencana melakukan pengecekan ke lokasi pembangunan peternakan ayam tersebut, diketahui bahwa ternyata benar peternakan ayam ini berada di tengah-tengah pemukiman warga, sehingga wajar apabila masyarakat melakukakn protes kepada pemerintah Kecamatan Gunung Kencana. Dari hal tersebut maka pihak Pemerintah Gunung Kencana pun sepakat dengan protes yang dilayangkan masyarakat, karena pembangunan peternakan ayam yang dibangun didekat pemukiman warga tentu akan menghasillkan bau busuk yang akan mengganggu dan mencemari udara.

Pertimbangan keempat pendirian peternakan ayam yang dibangun di Desa Ciakar ini melanggar PERDA Kabupaten Lebak tentang Rencana Tata Ruang Wilayah (RTRW) karena berdasarkan peraturan daerah tersebut diputuskan bahwa secara tata ruang Kecamatan Gunung Kencana terutama di Desa Ciakar tidak boleh digunakan untuk peternakan 
DOI: $10.34010 /$ agregasi.v8i1.3061

Available online at: https://ojs.unikom.ac.id/index.php/agregasi

ayam, hal tersebut lantaran desa ciakar merupakan Desa yang dihuni oleh banyak penduduk dan secara tata ruang memang tidak cocok. Selain itu pendirian peternakan ayam di Desa ciakar ini juga melanggar PERDA Kabupaten Lebak No. 9 Tahun 2010 tentang retribusi perizinan tertentu. pendirian peternakan ayam ini dianggap melanggar PERDA tersebut karena pada awal pembangunannya tidak mengantongi izin dari pemerintah sehingga tidak tercatat dalam bangunan atau usaha yang berada di Kecamatan Gunung Kencana, dan apabila hal tersebut terjadi maka berarti bangunan yang berdiri serta usaha yang akan berjalannya tidak akan di kenai retribusi daerah dan tidak akan membayar biaya retribusi tersebut. Alhasil atas pertimbangan itu maka peternakan ayam ini melanggar PERDA tentang retribusi daerah.

Menyikapi aksi protes yang dilakukan oleh masyarakat Desa Ciakar kepada pemerintah kecamatan gunung kencana tersebut, maka hal ini sejalan dengan apa yang dikatakan oleh Choen mengenai gerakan sosial baru, yang mana gerakan tidak hanya muncul akibat adanya ketertindasan kaum proletar oleh kaum borjuis semata atau gerakan yang berhubungan dengan sistem produksi dan ekonomi, layaknya gerakan sosial lama. Tapi gerakan sosial yang terjadi disini mencerminkan gerakan sosial baru karena muncul dari kalangan masyarakat biasa serta lebih pada gerakan akar akar rumput, karena berawal dari dari bawah, yaitu masyarakat lalu kemudian mengadu kepada pemerintah kecamatan agar menghentikan pembangunan peternakan ayam karena akan mengganggu mereka. Selain itu gerakan ini juga lebih mengedepankan tujuan, dimana masyarakat yang melakukan gerakan tidak memiliki atau didasari dengan kepentingan lain diluar tujuan mereka untuk agar pembangunan peternakan ayam dihentikan, karena jika tetap dibangun maka akan mengganggu atau mencemari lingkungan. Selain itu gerakan yang dilakukan oleh masyarakat Gunung Kencana dalam menolak pendirian peternakan ayam ini juga dapat dikatan sebagai gerakan sosial baru karena salah satu isu yang paling sering dikaitkan dengan gerakan sosial baru merupakan isu lingkungan (Singh, 2010). Selanjutnya apabila dilihat dari parameter gerakan sosial baru yang dikemukakan oleh cohen maka gerakan ini juga termasuk gerakan sosial karena adanya struktur persamaan politik yang dibangun oleh penggerak dalam menyamakan persepsi masyarakat untuk menolak pendirian peternakan ayam tersebut, kemudian dalam gerakan sosial pendirian peternakan ayam ini juga menunjukan adanya struktur mobilisasi massa yang terorganisir melaui musyawarah masyarakat yang berujung pada pengumpulan foto copy KTP bagi masyarakat yang menyepakati. Dan yang terakhir adalah adanya framing yang dibangun dilingkungan masyarakat bahwa pendirian peternakan ayam tersebut akan mengganggu kenyamanan apabila nanti diisi oleh ribuan ayam (Arfiyani, 2014). 
DOI: $10.34010 /$ agregasi.v8i1.3061

Available online at: https://ojs.unikom.ac.id/index.php/agregasi

Selanjutnya melihat proses penghentian pembangunan peternakan ayam di Desa Ciakar di Kecamatan Gunung Kencana oleh Pemerintah Kecamatan Gunung Kencana yang dihadiri oleh MUSPIKA Kecamatan Gunung Kencana menunjukan adanya proses politik yang terjadi karena hal ini berhubungan dengan kebijakan yang diambil oleh pemerintah Gunung Kencana atas pertimbangan beberapa hal yang dianggap menjadi dasar ataupun alasan bagi Pemerintah Kecamatan Gunung Kencana untuk akhirnya memutuskan penghentian pembangunan peternakan ayam. Proses politik tersebut dapat dikatakan sebagai politik lingkungan karena kebijakan yang diputuskan oleh Pemerintah Kecamatan Gunung Kencana merupakan bagian dari upaya stabilisasi lingkungan. Selain itu gerakan ini dapat dikatakan berhubungan dengan politik lingkungan karena menurut Yeni Sri Lestari (Lestari, 2016) bahwa politik lingkungan sangat erat kaitannya dengan Ekonomi Politik. Begitu pula dengan konflik yang terjadi di Kecamatan Gunung Kencana ini juga sangat erat kaitannya dengan ekonomi politik karena pendirian peternakan ayam ini merupakan bagian dari Industri yang berhubungan dengan perekonomian yang kemudian dihentikan pembangunannya oleh kebijakan politik yang diambil. Selain itu dalam jurnal Yeni Sri Lestari juga dikatakan bahwa lingkungan merupakan sumber dari segala kebutuhan materi dan energi namun seringkalli dijadikan tempat utama pembuangan sisa atau limbah industri hasil perekonomian. Hal ini selaras dengan apa yang terjadi di Desa Ciakar Kecamatan gunung Kencana, yang mana salah satu hal yang mendorong adanya gerakan penolakan dari masyarakat Desa Ciakar juga karena di khawatirkan apabila peternakan ayam telah jadi maka limbahnya akan dibuang secara sembarangan oleh pemilik peternakan tanpa memperhatikan kenyamanan lingkungan, sehingga pada akhirnya akan menimbulkan bau busuk yang mengganggu.

\section{Pihak - Pihak Yang Terlibat}

Dalam sebuah gerakan sosial yang berhubungan dengan politik lingkungan tentu dilatar belakangi oleh beberapa pihak yang menjadi aktor penggerak serta menjadi sosok yang bertanggung jawab terhadap gerakan yang digagas, terlebih apabila gerakan tersebut berhubungan dengan politik lingkungan seperti gerakan yang terjadi di Desa Ciakar Kecamatan Gunung Kencana. Dalam gerakan penolakan pendirian peternakan ayam yang dilakukan oleh masyarakat Desa Ciakar tidak hanya melibatkan peran masyarakat yang memprotes kepada pemilik peternakan, melainkan banyak pihak lain yang turut mendukung gerakan tersebut hingga akhirnya membuahkan hasil seperti yang diinginkan. Semua pihak yang terlibat dalam gerakan sosial lingkungan ini memiliki peran masing-masing yang kemudian membuat gerakan ini menjadi masif.

Pertama masyarakat, dalam hal ini masyarakatlah yang menjadi orang 
DOI: $10.34010 /$ agregasi.v8i1.3061

Available online at: https://ojs.unikom.ac.id/index.php/agregasi

yang dirugikan sekaligus inisiator utama dalam gerakan sosial penolakan pendirian peternakan ayam ini, karena apabila pembangunan peternakan ayam ini terus dilanjutkan tanpa adanya penolakan dari masyarakat maka masyarakat pula lah yang paling dirugikan nantinya.

Kedua pemerintah, peran pemerintah begitu sentral dalam proses politik lingkungan, karena pemerintahlah yang menjadi penentu kebijakan untuk menghentikan atau tidak pendirian peternakan ayam di Kecamatan Gunung Kencana atas protes masyarakat mengenai keberatannya akibat adanya peternakan yang akan dibangun.

Ketiga pengusaha, yang terdiri dari pemilik peternakan ayam dan pemborong proyek pembangunan peternakan ayam. Keduanya menjadi objek gugatan masyarakat yang kemudian berujung pada laporan kepada pemerintah selaku pemangku kebijakan. Selain itu peran pengusaha disini juga menjadi penyebab gerakan sosial ini terjadi karena permasalahan ini bermula dari pengusaha bernama Rizaldi yang membangun peternakan ayam disembarang tempat tampa izin serta tidak mempertimbangkan aspek sosial lingkungan. Sedangkan peran pemborong proyek dalam hal ini menjadi aktor yang paling dirugikan apabila pembangunan peternakan ayam dihentikan, karena dengan begitu berarti material bangunan yang sudah dibeli dan di sediakan untuk membangun peternakan ayam menjadi tidak terpakai dan akan memicu adanya ketidak pastian pembayaran dari pemilik peternakan apabila peternakan tidak sampai selesai dibangun.

Keempat adalah Organisasi Masyarakat, dalam proses pendirian peternakan ayam ini salah satu organisasi masyarakat yang terlibat adalah Himpunan Mahasiswa Gunung Kencana (HIMAGUNA) yang kemudian turut melayangkan surat penolakan pendirian peternakan ayam di Desa Ciakar kepada Pemerintah Kecamatan Gunung Kencana sebagai tindak lanjut ataupun bentuk dukungan terhadap surat yang dilayangkan oleh masyarakat Desa Ciakar. Selain itu HIMAGUNA juga berperan sebagai aktor yang memviralkan kasus ini ke media baik itu di Instagram HIMAGUNA dan anggotaanggotanya, maupun dengan memanggil wartawan dari beberapa situs berita untuk kemudian meliput persoalan ini sehingga bisa diketahui oleh publik.

Dari beberapa fungsi yang dilakukan oleh masing-masing pihak yang terlibat, pada dasarnya merupakan bagian dari upaya untuk melestarikan lingkungan, karena gerakan gerakan tersebut berkaitan dengan Environtalisme yang mana menurut WALHI bahwa Environtalisme dapat dikatakan sebagai gerakan yang konsen terhadap permasalahan sosial yang berhubungan = dengan manusia dan makhluk hidup lainnya termasuk diantaranya lingkungan yang erat kaitannya dengan manusia yang hidup didalamnya (WALHI, 2008). 
DOI: $10.34010 /$ agregasi.v8i1.3061

Available online at: https://ojs.unikom.ac.id/index.php/agregasi

\section{Pembangunan Peternakan Ayam Tetap Berlanjut}

Setelah adanya surat penghentian pembangunan peternakan ayam di Desa Ciakar yang dilayangkan oleh Pemerintah Kecamatan Gunung Kencana melalui surat dengan Nomor: 300/3/Kec/2020 kepada pemilik peternakan yang bernama Rizaldi sebagai tindak lanjut atas surat pernyataan penolakan yang dilayangkan oleh warga Desa Ciakar serta surat yang dilayangkan oleh ketua BPH HIMAGUNA dengan Nomor: 001/PN/PKA/BPH-HIMAGUNA/I/2020

pada tanggal 28 Januari 2020, maka pihak Kecamatan Gunung Kencana pun turun langusung ke lapangan bersama MUSPIKA Kecamatan Gunung Kencana untuk menghentikan pembangunan. Alhasil pembangunan pun dihentikan sampai adanya perizinan yang jelas dari pemerintah serta tindak lanjut dari pemilik peternakan ayam. Akan tetapi beberapa hari setelah penghentian dilakukan, pengerjaan pembangunan kembali di lanjutkan oleh pemborong proyek yang bernama Afrizal dengan dalih karena pemborong tidak tahu menahu dan tidak peduli dengan permasalahan izin maupun yang lainnya karena mereka hanya pemborong proyek yang harus menyelesaikan bangunan yang sudah dibuat, adapun nantinya apakah pembangunan tersebut akan diisi ayam atau tidak, itu diluar dari urusan pemborong proyek, sehingga pembangunan tetap berjalan hingga sekarang.

Menyikapi hal tersebut pihak Pemerintah Kecamatan Gunung Kencana tidak diam begitu saja melainkan kembali menindak lanjuti penghentian yang dilakukannya dengan melakukan Audiensi bersama pihak dari perwakilan pemilik peternakan. Hasil dari audiensi tersebut pihak Pemerintah Kecamatan Gunung Kencana memutuskan bahwa pembangunan tetap boleh dilanjutkan sampai selesai dengan syarat tidak boleh diisi oleh peternakan ayam ataupun peternakan lainnya. Namun diluar daripada itu pemilik bangunan tersebut harus tetap mengurus izin pendirian bangunan yang hampir jadi tersebut serta tetap membayar uang retribusi daerah apabila bangunan tersebut digunakan untuk kepentingan usaha yang lain.

Dari beberapa runtutan proses gerakan sosial penolakan peternakan ayam di Gunung Kencana ini hingga peristiwa yang terjadi pasca penghentian paksa oleh Pemerintah Kecamatan Gunung Kencana, sejatinya menunjukan adanya Konflik yang terjadi dimasyarakat yang melibatkan masyarakat dengan pengusaha, serta pengusaha dengan Pemerintah. Hal ini didasarkan pada pernyataan Wees Sharrock yang menerangkan bahwa akibat adanya kepentingan dimasyarakat terkadang masyarakat akan diorganisir sedemikian rupa sehingga tidak hanya memberikan manfaat yang lebih besar bagi yang lain akan tetapi juga memberikan ketidak nyamanan bagi masyarakat lain yang tidak memperoleh kemudahan.

Jika melihiat gerakan sosial yang di inisiasi oleh masyarakat Desa Ciakar 
DOI: $10.34010 /$ agregasi.v8i1.3061

Available online at: https://ojs.unikom.ac.id/index.php/agregasi

menunjukkan bahwa adanya salah satu anggota masyarakat yang memberikan ketidak nyamanan (pemilik peternakan ayam) bagi masyarakat yang lain (masyarakat desa ciakar) sehingga memicu konflik antara keduanya hingga akhirnya berujung pada penolakan pendirian peternakan ayam karena dirasa akan mengganggu kenyamanan akibat bau busuk dari kotoran ayam yang akan mencemari udara dan lingkungan sekitar.

\section{KESIMPULAN}

Konflik yang terjadi di Kecamatan Gunung Kencana akibat adanya pendirian peternakan ayam di Desa Ciakar pada dasarnya diawali dari keresahan masyarakat sekitar lingkungan peternakan, yaitu masyarakat Desa Ciakar yang khawatir akan terganggu kenyamanannya akbiat bau busuk yang akan ditimbulkan dari kotoran ayam yang berjumlah banyak. Dari keresahan masayarakt tersebut akhirnya memicu gerakan sosial penolakan yang dilakukan oleh masyarakat dengan mengungplkan KTP dan penandatanganan berkas untuk kemudian melayangkan surat penolakan kepada pemerintah Kecamatan Gunung Kencana. Aksi yang dilakukan oleh masyarakat tersebut juga didukung oleh HIMAGUNA yang kemudian melayangkan surat penolakan juga.

Berangkat dari surat penolakan dari masyarakat dan HIMAGUNA, serta mempertimbangkan beberapa aspek lainnya, seperti pendirian bangunan peternakan yang tanpa izin terlebih dahulu kepada Dinas Penanaman Modal Terpadu Satu Pintu (DPMPTSP) Kabupaten Lebak, pembangunan peternakan yang melangar PERDA Kabupaten Lebak No.2 Tahun 2014 tentang rencana tata ruang wilayah (RTRW) dan peraturan daerah No.9 Tahun 2010 tentang retribusi perijinan tertentu, dan setelah melakukan pengecekan langsung ke lapangan, maka pada akhirnya pemerintah Kecamatan Gunung Kencana menghentikan secara paksa pembangunan peternakan ayam tersebut melalui surat yang dilayangkan kepada pemelik peternakan serta berdialog dengan pemborong proyek.

Kemudian setelah pemerintah Kecamatan Gunung Kencana melayangkan surat penghentian pembangunan secara paksa, pembangunan tetap dilanjutkan, karena mempertimbangkan kerugian yang akan berdampak pada pemborong proyek apabila proyek dihentikan. Walau demikian, pemerintah Kecamatan Gunung Kencana tetap menekankan bahwa ketika pembangunan peternakan ayam sudah selesai maka tidak boleh dipergunakan untuk peternakan apapun, namun pemilik bangunan harus tetap membayar retribusi apabila digunakan untuk jenis usaha lain serta tetap harus mengurus perizinan pendirian bangunan kepada DPMPTSP.

\section{DAFTAR PUSTAKA}

Arfiyani. 2014. New A Social Movement. Yogyakarta: Be True Muslim 
JURNAL AGREGASI

Jurnal Aksi Reformasi Government Dalam

Demokrasi

Volume 8- Nomor 1, Mei 2020

DOI: $10.34010 /$ agregasi.v8i1.3061

Available online at: https://ojs.unikom.ac.id/index.php/agregasi

Bell, M.V., R.J. Henderson dan J.R. Sargent. 1986. The role of polyunsatureted fatty acids in fish. Mini Review. Comp. Biochem. Physiology, 83B:711-719.

Cahyono, Edi. 2018. Gerakan Sosial dan Masayarakat Sipil dalam Menolak Pendirian Pabrik Semen di Rembang: Study Kasus Peran Advokasi JM-PPK. Tesis. UIN Sunan Kalijaga Yogyakarta

Giddens. 1984. Constitution of Society: The Outline of the Theory of Structuration. Cambridge: Polity Press 1984

Jones, P. 2009. Pengantar Teori-Teori Sosial dari Teori Fungsionalisme hingga Post-Modernisme. terj., Achmad Fedyani Saifuddin. Jakarta: Yayasan Obor Indonesia.F

Lestari, Yeni Sri. 2016. Environmental dan Green Politics: Pembahasan Teoritis. Jurnal Community: Volume 2, Nomor 2.

Mas'udi. 2015. Akar-Akar Teori Konflik: Dialektika Konflik: Core Perubahan Sosial dalam Pandangan Karl Marx dan George Simmel. FIKRAH: Jurnal Ilmu Aqidah dan Studi Keagamaan Volume 3, No.1.

Oktaviana, Ganies. 2015. Analisis Konflik Sumberdaya Alam di Pegunungan Kendeng Utara Kabupaten Pati, Provinsi Jawa Tengah (Study Kasus: Rencana Pembangunan
Pabrik Semen oleh PT. SMS di Kecamatan Tambakromo dan Kayen). Tesis. Institut Pertanian Bogor.

Satelitnews. 2020. Keberadaan Peternakan Ayam Ditolak Warga. Diakses dari Satelitnews.id: https://www.satelitnews.id/130 9/keberadaan-peternakan-ayamditolak-warga/

Singh, Rajendra. 2010. Gerakan Sosial Baru. Magelang: Riset Book

Situmorang, Abdul Wahab. 2011. Dinamika Proses Kolektif Lingkungan Hidup di Indonesia. Yogyakarta: Pustaka Pelajar

Surapto. 2019. Gerakan Sosial Masyarakat Sipil Dalam Penolakan Pabrik Karet di Desa Medali. Tesis. Univeristas Muhammadiyah Malang.

WALHI. 2008. Menjadi Environmentalis itu Gampang: Sebuah Panduan bagi Pemula. Jakarta Selatan. 